\title{
The Influence of Extruded Feed with a high Protein Level Upon the Bioproductive Performances Obtained on the Rainbow Trout Females (Oncorhynchus mykiss)
}

\author{
Anca BOARU ${ }^{1}$, Daniel MIERLIȚA ${ }^{2}$, Bogdan GEORGESCU ${ }^{1}$, Cristina ELMAHDY ${ }^{1 *}$ \\ ${ }^{1}$ Faculty of Animal Science and Biotechnologies, University of Agricultural Sciences and Veterinary \\ Medicine Cluj-Napoca, Romania, EU; \\ ${ }^{2}$ Department of Animal Science, University of Oradea, Romania, EU. \\ * corresponding author: cristina.hegedus@yahoo.com
}

Bulletin UASVM Animal Science and Biotechnologies 73(2)/ 2016

Print ISSN 1843-5262; Electronic ISSN 1843-536X

DOI:10.15835/buasvmcn-asb: 12197

\begin{abstract}
The succes of artificial reproduction in the rainbow trout (Oncorhynchus mykiss), the development of gonads and the results obtained at incubation are significantly affected by the feeding of the breeders. The use of quality sexual products is decisive for the assurance of the production of viable larvae and further more estimated fish production, so that in addition to the assurance of optimal environmental parameters, the proper feeding of the breeders is required. Starting from the current stage of knowledge in the field, the main objective of the working paper was to highlight the way that differentiated feeding of the rainbow trout females (Oncorhynchus mykiss) influences their growth and development. Also, have been followed the effects of the extruded granulated feed with a high protein level on egg weight and the gonosomatic index. The results obtained were structured according to the administrated feed and the age of the females, in identical growing conditions. The body development and performance of breeding obtained in rainbow trout females (Oncorhynchus mykiss) were significantly influenced by the quality of the administered feed. The extruded peeled feed with $53 \%$ protein proved to be highly effective, materialized trough high growth performances, a better conversion and the growth of gonadal weight.
\end{abstract}

Keywords: extruded feed, protein levels, rainbow trout.

\section{INTRODUCTION}

In breeding salmonids, as well as in other branches of aquaculture, the costs of food and feed account for $50-60 \%$ of the final production cost (Aba et al., 2012; Kaushik, 2000) and the chemical composition of the feed influences the energy recovery and implicitly the growth rate of fish (Azevedo, 1998; Boaru, 2007). Adjusting feed consumption in fish is influenced by digestibility and energetic value of the mixed fodder (Kaushik and Luquet, 1984), so that in order to satisfy protein and aminoacid needs, the relation digestible protein/digestible energy from the feed (Oprea,
2000 ) is very important. The energy requirements for the process of reproduction in fish can only be assessed in the long term, through the effort which corresponds to the energy stocked in gonads, in relation with the quantity of ingested energy.

For the majority of fish species, at maturity, the male gonads represent approximately 10\% of the entire body weight, and in females they can represent up to $30 \%$ of the entire body weight. The average energy content of the eggs, in the majority of fish species is aproximatly $23.5 \mathrm{Kj} / \mathrm{g}$ dry matter, regardless of their size. In salmonids, the quantity of stored energy in eggs represents $8-15 \%$ of the 
entire body energy, which corresponds to the gonosomatic index (Boaru, 2010; Guillaume et al., 1999).

The effects of feeding level, water temperature, composition and preparation mode of the feed on the growth performances and on the use and nutrient assimilation and energy by the salmonids, have been the subject of many studies and speciality research and the results obtained are different (Blom, 1995; Bozkurt, 2006; Gavriilidou, 2003; Memis, 2004). The succes of artificial reproduction, the development of gonads, the fecundity and the results obtained during incubation are highly affected from the feeding of the breeders (Izquierdo et al., 2001). Under this aspect, an important part is played by nutrients which are contained in the feed and the quantity and quality of the sexual products can be improved through the insurance of the nutritive quantity and quality of the breeders feed (Boaru, 2010). This can be tackled by using the granulated feed, the reduction of the specific consumption and reduction of nutrient losses. Extruded feed offers the advantage of increasing the digestibility, proper texture, low fiability and better floatability (Aba et al., 2012; Oprea, 2000).

The main objective of the study is to highlight the way that the differential feeding of rainbow trout females (Oncorhynchus mykiss) has influenced their growth and development. Also, the effects of the extruded granulated feed with a high protein level on egg weight and the gonosomatic index have been followed.

\section{MATERIALS AND METHODS}

The research has been conducted at the Remeți trout farm (Bihor county, Romania), and the biological material was rainbow trout (Oncorhynchus mykiss) female, which represented the breeding nucleus during 2004-2006. Located at an altitude of $435 \mathrm{~m}$, the Remeți trout farm has two sources of water, providing an average annual flow rate of $600 \mathrm{~L} / \mathrm{min}$, while the temperature of the water has values between $0-21^{\circ} \mathrm{C}$, the annual average being $11^{\circ} \mathrm{C}$ (Tab. 1). The basins are built of concrete and are most likely to be found in many classic trout farms in Romania. Two experimental groups have been designed (C-control, E-high protein), each one formed of 100 females, which have been distributed in the breeders basins at a density of 3 specimens $/ \mathrm{m}^{2}$. For the feeding of the fish, two types of granulated feed have been used, differentiated both in terms of chemical composition and method of production. The first group (C) has been fed with a classic natural feed with a proteic level of $46 \%$, and for the second group (E), an extruded feed with a proteic level of $53 \%$ has been used (Tab. 2).

The differented feeding of the rainbow trout females has started in 01.01.2004 and has ended in 2005, along with the triggering of the artificial reproduction process (21.01.2005). As a next step, the 3 year old females have been continually fed with the two feeds for one year, until the triggering of the reproductive process started (20.01.2006). The quantitive level of the feed has been established according to the water temperature and quantity of fish (\% of the entire body weight). Prior and during the breeding period body measurements have been performed on a total number of 30 specimens, randomly selected from each constituted group, while sexual products were collected, as well. The following traits were targeted: total length $(\mathrm{cm}) \mathrm{Lt}=$ the distance from the top of the snout till the top of the lobs of caudal fin; the large perimeter $(\mathrm{cm})$ $\mathrm{Pm}=$ the circumference of the body in the right largest height; the body weight $\mathrm{Mc}=$ the fish were weighed before the harvesting of eggs; the eggs weight $(\mathrm{g}) \mathrm{Mi}=$ the harvested eggs were weighed; the gonosomatic index (\%) IG = the procentual reporting of the egg weight and the entire body weight.

Tab.1. The water temperature from the trout farm in Remeti according to season

\begin{tabular}{ccc}
\hline Season & Minimum temperature ${ }^{\circ} \mathbf{C}$ & Maximal temperature ${ }^{\circ} \mathbf{C}$ \\
\hline Spring & 7 & 12 \\
\hline Summer & 14 & 21 \\
\hline Autumn & 12 & 14 \\
\hline Winter & 0 & 10 \\
\hline
\end{tabular}


The results obtained were structured according to the administrated feed and the age of the females, in identical growing conditions. The growth dynamic of the female rainbow trout from 2 years to 3 years and further up to 4 years was also recorded. The results regarding the mass eggs and gonosomatic index were also analyzed for the two reproductive cycles. Data were statistically analyzed using the Graph Pad Inst 3 programme to highlight the statistical differences between the averages of the two groups (test „t” $\mathrm{p}<0.05$ ).

\section{RESULTS AND DISCUSSION}

In terms of the chemical parameters of water (Tab. 3), the results obtained on the Remeti trout farm fall into category of water suitable for breeding rainbow trout, as the values correspond to the biological and physiological needs of rainbow trout (Order 161/2006).

The growth dynamic of the female rainbow trout ( $\mathrm{Pc}+$ ) from 2 to 3 years shows significant differences $(p<0.001)$ in favor of the second group (E), for every feature followed (Tab. 4). The ascending evolution shows the fact that the investements with feed and the energy from the content of the food were used efficiently, but the big differences between those two groups overtly show the performance of group $E$ which was fed with pelleted feed and highest protein level of 7\%. The results obtained in increasing body weight reveal the results provided by studies and research performed by Blom and Dabrowski (1995) or Memiș (2004), differences which claim the special influence and the effects of high protein levels from feed on growing performance in rainbow trout (Oncorhynchus mykiss).

Refering to the evolution of the females from 3 to 4 years old, the results obtained also highlighted the differences we followed (Tab. 5) and we observed, namely that the biological material continued its growth and development after the first artificial reproduction. For the second group (E), the 4 year old females grew with approximately $5 \mathrm{~cm}$ more than the first group (C), in terms of the large perimeter and the body weight, there were really significant differences $(p<0.001)$ between the two groups. We assessed the fact that the extruded feed with a high protein

Tab.2. The chemical composition of the two feeds, expressed as weight of the substance $\%$ for a grain size of $8 \mathrm{~mm}$

\begin{tabular}{|c|c|c|}
\hline Specification & Classic peeled feed & Extruded peeled feed \\
\hline Crude protein (Nx6.25) & 46 & 53 \\
\hline Crude fats & 16 & 20.40 \\
\hline Crude fibers & 1.70 & 1 \\
\hline$\overline{\mathrm{Ash}}$ & 9 & 9 \\
\hline Total phosphorus & 1.30 & 1.40 \\
\hline Digestible energy $(\mathrm{MJ} / \mathrm{kg})$ & 18 & 20.8 \\
\hline$\overline{\text { Raport CP/DE }}$ & 2.55 & 2.55 \\
\hline
\end{tabular}

Tab. 3. Chemical parameters of the water upon entrance and evacuation of the basins

\begin{tabular}{ccc}
\hline Determined parameters & Entrance & Evacuation \\
\hline pH unit.pH & 7.24 & 7.74 \\
\hline Hardness dH & 8.68 & 7.00 \\
\hline Sulphates $\mathrm{mg} / \mathrm{L}$ & 10.00 & 10.00 \\
\hline Chlorides $\mathrm{mg} / \mathrm{L}$ & 24.00 & 26.00 \\
\hline Nitrates $\mathrm{mg} / \mathrm{L}$ & - & 3.43 \\
\hline Nitrites mg/L & 0.005 & 0.05 \\
\hline Ammonia mg/L & $<0.005$ & 0.10 \\
\hline Iron mg/L & $<0.005$ & 0.10 \\
\hline Organic substance mg/L & 7.44 & 9.16 \\
\hline Oxygen mg/L & 11.00 & 9.00 \\
\hline
\end{tabular}


level assures the optimum level of energy with an assured effect on the growth performances in this species, aspect highlighted by Jobling (1993), quoted by Memis (2004).

For egg weight, we also recorded a difference between the two reproductive cycles and between the two groups. The largest egg quantity was obtained in the second reproductive cycle, at the age of 4 years, for both groups. As for the first group, a difference of $43 \mathrm{~g}$ was found between the two reproductive cycles under analysis and which is statistically significant $(p<0.01)$. For the second group, the difference was 75 grams higher, which proved to be highly significant statistically $(\mathrm{p}<0.001)$. For the gonosomatic index, the difference is highly significant statistically $(\mathrm{p}<0.001)$, while an insignificant statistical difference has been observed in the first group (C). For the second group (E), a difference in the favor of the 4 year old females was noticed.

The evolution from 3 to 4 years highlight the fact that the administration of high protein peletted feed greatly influenced the body development and egg quantity obtained from rainbow trout females. In the case of the extruded peeled with a high protein level of $53 \%$, the performances have been superior to the ones obtained in the first group (C), which was fed with classic peeled feed with a protein level of $46 \%$.

\section{CONCLUSION}

The body development and performance of breeding obtained in rainbow trout females (Oncorhynchus mykiss) were significantly influenced by the quality of the administered feed and the best results were obtained when the peleted feed with the high protein level of 53\% was used. Apart from the growth differences, the influence of high protein level and the type of administered feed on the quantity of the eggs obtained can also be observed, the best performance being achieved by the second lot.

The growth rate and body weight accumulated was higher in the 2-3 years interval for both cases. In the case of the extruded peleted feed, the high energy content was mostly due to the production technology, but also because of the high protein level has significantly contributed to the obtaining

Tab. 4. Differences between females Pc $q 2$ and 3 years

\begin{tabular}{cccccccc}
\hline \multicolumn{2}{c}{ Feature } & $\mathbf{P c}+\mathbf{2}$ & $\mathbf{P c}+\mathbf{3}$ & $\mathbf{d}$ & $\mathbf{t}$ & Statistical & significance \\
\hline $\mathrm{Lt}$ & $\mathrm{C}$ & $22.17 \pm 0.47$ & $38.73 \pm 0.82$ & 16.56 & 17.52 & $* * *$ & $\mathrm{p}<0.001$ \\
& $\mathrm{E}$ & $22.39 \pm 0.47$ & $50.48 \pm 0.38$ & 28.09 & 46.48 & $* * *$ & $\mathrm{p}<0.001$ \\
\hline \multirow{2}{*}{$\mathrm{Pm}$} & $\mathrm{C}$ & $12.44 \pm 0.16$ & $23.17 \pm 0.48$ & 10.73 & 29.21 & $* * *$ & $\mathrm{p}<0.001$ \\
& $\mathrm{E}$ & $12.71 \pm 0.16$ & $21.29 \pm 0.44$ & 8.58 & 39.68 & $* * *$ & $\mathrm{p}<0.001$ \\
\hline \multirow{2}{*}{ Mc } & $\mathrm{C}$ & $466.99 \pm 121$ & $833.90 \pm 34.23$ & 366.91 & 10.09 & $* * *$ & $\mathrm{p}<0.001$ \\
& $\mathrm{E}$ & $471.65 \pm 12.26$ & $1494.68 \pm 24.92$ & 1023.03 & 36.84 & $* * *$ & $\mathrm{p}<0.001$ \\
\hline
\end{tabular}

Pc $q$ 2=rainbow trout females 2 year; Pc $q$ 3=rainbow trout females 3 year; Lt=Total length $(\mathrm{cm})$; $\mathrm{Pm}=$ Large perimeter $(\mathrm{cm})$; Mc=Body weight $(\mathrm{g})$.

Tab. 5. Differences between females Pc $q 3$ and 4 years

\begin{tabular}{|c|c|c|c|c|c|c|c|}
\hline \multicolumn{2}{|c|}{ Feature } & \multirow{3}{*}{$\begin{array}{c}\mathbf{P c}+\mathbf{3} \\
38.73 \pm 0.82 \\
50.48 \pm 0.38\end{array}$} & \multirow{3}{*}{$\begin{array}{c}\mathbf{P c}+\mathbf{4} \\
41.67 \pm 0.40 \\
55.43 \pm 0.56\end{array}$} & \multirow{3}{*}{$\frac{\text { d }}{2.94}$} & \multirow{2}{*}{$\frac{\mathbf{t}}{3.22}$} & \multicolumn{2}{|c|}{ Statistical significance } \\
\hline $\mathrm{Lt}$ & $\mathrm{C}$ & & & & & $* *$ & $\mathrm{p} \geq 0.01$ \\
\hline & $\mathrm{E}$ & & & & 7.31 & $* * *$ & $\mathrm{p}<0.001$ \\
\hline \multirow[t]{2}{*}{$\mathrm{Pm}$} & $\mathrm{C}$ & $23.17 \pm 0.48$ & $28.96 \pm 0.37$ & 5.79 & 9.55 & $* * *$ & $\mathrm{p}<0.001$ \\
\hline & $\mathrm{E}$ & $31.29 \pm 0.44$ & $33.13 \pm 0.39$ & 1.84 & 3.13 & $* *$ & $\mathrm{p} \geq 0.01$ \\
\hline \multirow[t]{2}{*}{$\mathrm{Mc}$} & $\mathrm{C}$ & $833.90 \pm 34.23$ & $1017.40 \pm 26.44$ & 183.50 & 4.24 & $* * *$ & $\mathrm{p}<0.001$ \\
\hline & $\mathrm{E}$ & $1494.68 \pm 24.92$ & $2345.13 \pm 33.03$ & 850.45 & 20.55 & $* * *$ & $\mathrm{p}<0.001$ \\
\hline \multirow[t]{2}{*}{$\mathrm{Mi}$} & $\mathrm{C}$ & $150.43 \pm 15.96$ & $193.47 \pm 12.38$ & 43.04 & 2.13 & $*$ & $\mathrm{p}<0.01$ \\
\hline & $\mathrm{E}$ & $264.93 \pm 11.64$ & $339.93 \pm 11.88$ & 75.00 & 4.51 & $* * *$ & $\mathrm{p}<0.001$ \\
\hline \multirow[t]{2}{*}{ IG } & $\mathrm{C}$ & $10.86 \pm 0.36$ & $11.44 \pm 0.49$ & 0.58 & 0.95 & ns & $\mathrm{p}=0.344$ \\
\hline & $\mathrm{E}$ & $17.38 \pm 0.60$ & $19.41 \pm 0.99$ & 2.03 & 1.75 & $*$ & $\mathrm{p}=0.043$ \\
\hline
\end{tabular}
weight (g); Mi =Weight of roes (g); IG=Gonosomatic index (\%). ns=not significant. 
of performances in terms of growth and superior reproduction for rainbow trout females.

\section{REFERENCES}

1. Aba M, Driss B, Khadija E, Mohammed B, Aziz M (2012). Effects of pressed and extruded foods on growth performance and body composition of rainbow trout (Oncorhynchus mykiss). Pakistan Journal of Nutrition 11(2):104-109.

2. Azevedo PA (1998). Effects of feeding level, water temperature and diet composition on growth and efficency of feed utilization in two salmonids. A thesis presented to the Faculty of Graduate Studies of the University of Guelph.

3. Boaru A (2007). Comparative study of the growing performances in rainbow trout (Oncorhynchus mykiss) and brook trout (Salvelinus fontinalis). Bulletin USAMV Cluj-Napoca 63-64:530.

4. Boaru A (2010). Comparative re research on different feeding technologies in breeders of rainbow and brook trout on breeding, production and economics índices. PhD thesis, UASVM Cluj-Napoca.

5. Blom JH, Dabrowski K (1995). Reproductive success of female rainbow trout (Oncorhynchus mykiss) in response to graded dietary ascorbyl monophosphate levels. Biology of Reproduction 52:1073-1080.

6. Bozkurt Y (2006). The relationship between body condition, sperm quality parameters and fertilization success in rainbow trout (Oncorhynchus mykiss). Journal of Animal and Veterinary Advances 5(4):284-288.

7. Committee on Animal Nutrition Board on Agriculture. National Research Council (1993) Nutrient Requirements of fish. National Academy Press, Washington D.C.

8. Gavriilidou I, Fotis G, Batzios C (2003). Reproductive output of rainbow trout, Oncorhynchus mykiss (Walbaum), fed increasing levels of ascorbic acid. Pakistan Journal of Biological Sciences 6(19):1664-1671.

9. Guillaume J, Kaushik S, Bergot P, Métailler R (1999). Nutrition et alimentation des poissons et crustacés. INRA.

10. Izquierdo MS, Fernandez-Palacios H, Tacon AGJ (2001). Effect of broodstock nutrition on reproductive performance of fish. Aquaculture 197: 25-42.

11. Jobling M (1993). Nutrition, diet formulation and feeding practices. In: Heen K., Monahan R. L.,Utter F. (eds), Salmon Aquaculture, Fishing News Books. London 83-126.

12. Kaushik SJ, Luquet P (1984). Relationship between protein intake and voluntary energy intake as affected by body weight with an estimation of maintenance needs in rainbow trout. Zeitschrift für Tierphysiologie, Tierernhrung und Futtermittelkunde 57-69.

13. Kocaman M E, Bayir A, Sirkecioglu AN (2009). Comparison of hatchery performances of rainbow trout (Oncorhynchus mykiss), and brook trout (Salvelinus fontinalis) under the same environmental conditions. Journal of Animal and Veterinary Advances 8(7):1429-1431.

14. Memis D, Gûn H (2004). Effects of different diets on the growth performance, gonad development and body composition at first sexual maturity of rainbow trout (Oncorhynchus mykiss). Turk J Vet Anim Sci 28:315-322.

15. Oprea L (2000). Bazele nutriției peștilor. Ed Fundației Universitare "Dunărea de Jos" Galați.

16. Ordinul 161/2006 pentru aprobarea normativului privind clasificarea calității apelor de suprafață în vederea stabilirii stării ecologice a corpurilor de apă. MO 511/13.06.2006.

17. Pereira JOB, Reis-Henriques MA, Sanchez JL, Costa JM (1998). Effect of protein source on the reproductive performance of female rainbow trout, Oncorhynchus mykiss (Walbaum). Aquaculture Research 29:751-760. 